\title{
ANALISIS LAPORAN ARUS KAS UNTUK MENGUKUR LIKUIDITAS KOPERASI KREDIT SEDANA PADANG ASRI DI DENPASAR
}

\author{
Ni Kadek Wiliana Putri ${ }^{1}$ \\ Luh Putu Virra Indah Perdanawati ${ }^{2}$ \\ ${ }^{1,2}$ Fakultas Ekonomi Universitas Ngurah Rai, Bali, Indonesia \\ 1e-mail : wilianaputri@gmail.com
}

\begin{abstract}
ABSTRAK
Dalam melakukan analisis terhadap suatu perusahaan penting untuk menilai arus kas bersih yang dihasilkan perusahaan selama satu periode tertentu. Melalui analisis ini dapat dinilai kemungkinan perusahaan dalam menghasilkan kas dimasa yang akan datang dan kemampuan perusahaan untuk membayar kewajiban hutang jangka pendek maupun hutang jangka panjang. Data dianalisis menggunakan analisis rasio arus kas, yaitu : rasio arus kas terhadap kewajiban lancar, rasio cakupan kas terhadap bunga, rasio total hutang, dan rasio arus kas terhadap laba bersih. Hasil penelitian ini menunjukan tingkat likuiditas Koperasi Kredit Sedana Padang Asri memperlihatkan kondisi yang kurang baik jika diperbandingkan dengan nilai rasio yang dipersyaratkan berada di bawah satu yang berarti terdapat kemungkinan perusahaan tidak mampu membayar kewajiban lancar hanya dengan menggunakan arus kas operasi saja.
\end{abstract}

Kata kunci : Laporan Arus Kas, Likuiditas

\section{ABSTRACT}

In conducting an analysis of a company it is important to assess the net cash flow that the company produces for a given period. Through this analysis, it can be assessed the possibility of the company in generating cash in the future and the company's ability to pay short-term debt obligations and long-term debt. The data used in this study is secondary data regarding the income statement and balance sheet. Data were analyzed using cash flow ratio analysis, namely: cash flow to current liabilities ratio, cash to interest coverage ratio, total debt ratio, and cash flow ratio to net income. The results of this study show that the level of liquidity of the Padang Asri Sedana Credit Cooperative shows unfavorable conditions when compared with the required ratio value under one which means there is a possibility that the company cannot afford to pay current liabilities using only operating cash flows.

Keywords: Cash Flow Statement, Liquidity 


\section{PENDAHULUAN}

Perusahaan yang dianggap baik adalah perusahaan yang dapat menghasilkan laba, disamping itu juga dapat menghasilkan arus masuk kas bersih yang semakin meningkat dimasa yang akan datang. Laporan arus kas perusahaan sering digunakan untuk menggambarkan kesanggupan perusahaan dalam memenuhi biaya operasional dan kewajiban perusahaan.

Arus kas mempunyai peranan yang cukup besar terhadap likuiditas perusahaan, semakin besar aset lancar perusahaan berupa kas dibandingkan dengan seluruh kewajiban jangka pendek perusahaan berarti semakin tinggi juga tingkat likuiditas perusahaan dan begitu juga sebaliknya.

Likuiditas pada koperasi menunjukkan kemampuan untuk memenuhi kewajiban jangka pendeknya, seperti membayar hutang jangka pendek dan untuk membiayai kegiatan operasi yang ada di koperasi tersebut.

Koperasi merupakan lembaga yang menjalankan suatu kegiatan usaha dan pelayanan yang sangat membantu dan diperlukan oleh anggota koperasi dan masyarakat yang berupa pelayanan kebutuhan keuangan, perkreditan, kegiatan pemasaran, atau kegiatan lain. Koperasi Kredit Sedana Padang Asri merupakan koperasi yang berada di Perumahan Padang Asri, Padangsambian.

Tujuan dalam penelitian ini adalah untuk mengetahui seberapa jauh perkembangan usaha antar koperasi tersebut dari tahun ke tahun dan efektifitas pengelolaan koperasi.

Penelitian ini menganalisis Arus Kas Operasi (AKO), Arus Kas Investasi (AKI), Arus Kas Pendanaan (AKP), serta tingkat likuiditas pendekatan yang digunakan kuantitatif dengan subjek penelitian Koperasi Kredit Sedana Padang Asri. Untuk lebih memfokuskan kajian penelitian ini, maka berikut disajikan data laporan arus kas Koperasi Kredit Sedana Padang Asri periode 2016-2017 sebagai sumber informasi yang kemudian akan menjadi dasar analisis data dalam penelitian ini, yaitu sebagai berikut :

Tabel 1

Laporan Arus Kas Koperasi Kredit Sedana Padang Asri Tahun 2016 - 2017

\begin{tabular}{|l|r|r|}
\hline \multicolumn{1}{|c|}{ Uraian } & $\mathbf{2 0 1 6}$ & $\mathbf{2 0 1 7}$ \\
\hline Arus Kas dari : & $(52.572 .112)$ & $(2.289 .667)$ \\
\hline $1 . \quad$ Aktivitas Operasi & $(34.179 .557)$ & $(30.489 .523)$ \\
\hline 2. Aktivitas Investasi & 111.331 .245 & 32.547 .127 \\
\hline $\begin{array}{l}\text { 3. Aktivitas } \\
\text { Pendanaan }\end{array}$ & 24.579 .576 & $(232.063)$ \\
\hline $\begin{array}{l}\text { Kenaikan (penurunan) } \\
\text { Bersih kas dan setara kas }\end{array}$ & 31.050 .630 & 55.630 .206 \\
\hline $\begin{array}{l}\text { Kas dan setara kas awal } \\
\text { tahun }\end{array}$ & 55.630 .206 & 55.398 .143 \\
\hline $\begin{array}{l}\text { Kas dan setara kas akhir } \\
\text { tahun }\end{array}$ & & \\
\hline
\end{tabular}

Sumber: Lampiran Laporan Arus Kas Koperasi Kredit Sedana Padang Asri, 2016-2017 


\section{METODE PENELITIAN}

Desain penelitian yang digunakan dalam penelitian ini adalah desain kuantitatif, yaitu data yang berupa angka-angka atau data yang dapat dihitung serta dapat dianalisis secara sistematis. Teknik pengumpulan data yang digunakan dalam penelitian ini dilakukan dengan observasi, wawancara, dan studi dokumentasi. Teknik analisis data yang dipergunakan dalam penelitian ini adalah rasio arus kas menurut Hery (2015:124) yaitu sebagai berikut :

a) Rasio Arus Kas Operasi Terhadap Kewajiban Lancar

Rasio ini menunjukkan kemampuan asrus kas operasi perusahaan dalam melunasi kewajiban lancarnya. Rasio ini dihitung sebagai hasil bagi antara arus kas operasi dengan total kewajiban lancar.

b) Rasio Cakupan Kas Terhadap Bunga (CKB)

Rasio ini menununjukkan kemampuan perusahaan dalam membayar bunga atas hutang yang ada, yang dimana dananya bersumber dari arus kas operasi perusahaan. Rasio ini dihitung sebagai hasil bagi arus kas operasi ditambah kas yang dibayarkan untuk bunga dan pajak dengan kas yang dibayarkan untuk bunga. c) Rasio Total Hutang

Rasio arus kas operasi terhadap total hutang menunjukkan kemampuan arus kas operasi perusahaan dalam melunasi seluruh kewajibannya, baik kewajiban lancar maupun kewajiban jangka panjang. Rasio ini dihitung sebagai hasil bagi antara arus kas operasi dengan total hitung.

d) Rasio Arus Kas Terhadap Laba Bersih Rasio arus kas operasi terhadap laba bersih menunjukkan seberapa jauh penyesuaian dan asumsi akuntansi aktual mempengaruhi perhitungan laba bersih. Rasio ini dihitung sebagai hasil bagi antara arus kas operasi dengan laba bersih.

\section{HASIL DAN PEMBAHASAN Uji Asumsi Klasik}

Rasio Arus Kas Operasi merupakan rasio untuk menghitung kemampuan arus kas operasi dalam membayar kewajiban lancar. Perhitungan rasio arus kas operasi dilakukan dengan cara membandingkan antara jumlah arus kas operasi dengan kewajiban lancar.

Tabel 2

Hasil Perhitungan Rasio Arus Kas Operasi Terhadap Kewajiban Lancar

\begin{tabular}{|c|c|c|}
\hline Tahun & $\begin{array}{c}\text { Hasil } \\
\text { Perhitungan }\end{array}$ & Presentase \\
\hline 2016 & $-0,067$ & $-6,7 \%$ \\
\hline 2017 & $-0,002$ & $-0,2 \%$ \\
\hline
\end{tabular}

Sumber: Data diolah menggunakan Excel, 2019

Berdasarkan perhitungan pada tabel 2 dapat diketahui arus kas operasi terhadap kewajiban lancar koperasi setiap tahun menunjukkan nilai yang rendah dan dapat dikategorikan kurang baik karena kurang dari standar rasio yaitu satu, maka dapat dikatakan bahwa koperasi tidak cukup memiliki kemampuan yang lebih dalam menyelesaikan kewajiban lancarnya hanya dengan menggunakan arus kas operasinya di 
tahun tersebut tanpa dukungan aktivitas lain dari pemanfaatan arus kas koperasi.

\section{Rasio Cakupan Kas Terhadap Bunga (CKB)}

Rasio ini digunakan untuk mengetahui kemampuan perusahaan dalam membayar bunga atas hutang yang telah ada.

Tabel 3

Hasil Perhitungan Rasio Cakupan Kas Terhadap Bunga (CKB)

\begin{tabular}{|c|c|c|}
\hline Tahun & $\begin{array}{c}\text { Hasil } \\
\text { Perhitungan }\end{array}$ & Presentase \\
\hline 2016 & $-31,967$ & $-3.196,7 \%$ \\
\hline 2017 & 1,904 & $190,4 \%$ \\
\hline
\end{tabular}

Sumber: Data diolah menggunakan Excel, 2019

Berdasarkan perhitungan pada tabel 3 dapat dilihat bahwa cakupan arus kas terhadap bunga pada Koperasi Kredit Sedana Padang Asri, untuk tahun 2016

adalah sebesar $\quad-31,967$ yang berarti bahwa kemampuan arus kas operasi dalam menutup biaya bunga adalah kurang dari 31 kali lipat total arus kas operasi yang dimiliki oleh koperasi.

Pada tahun 2017 cakupan arus kas terhadap bunga pada Koperasi Kredit Sedana Padang Asri mengalami peningkatan yaitu sebesar 1,904 yang berarti bahwa kemampuan arus kas operasi dalam menutup biaya bunga adalah hampir 2 kali dari total arus kas operasi yang dimiliki oleh koperasi.

\section{Rasio Total Hutang}

Rasio total hutang merupakan rasio untuk mengukur kemampuan arus kas operasi perusahaan dalam melunasi seluruh kewajibannya. Rasio ini menunjukkan jangka waktu pembayaran hutang oleh perusahaan dengan asumsi semua arus kas operasi digunakan untuk membayar hutang.

Tabel 4

Hasil Perhitungan Rasio Total Hutang

\begin{tabular}{|c|c|c|}
\hline Tahun & $\begin{array}{c}\text { Hasil } \\
\text { Perhitungan }\end{array}$ & Presentase \\
\hline 2016 & $-0,067$ & $-6,7 \%$ \\
\hline 2017 & $-0,002$ & $-0,2 \%$ \\
\hline
\end{tabular}

Sumber : Data diolah menggunakan Excel, 2019

Berdasarkan perhitungan pada tabel 4 dapat diketahui arus kas operasi terhadap total hutang koperasi setiap tahun menunjukkan nilai yang rendah dan dapat dikategorikan kurang baik karena kurang dari standar rasio yaitu satu, 
maka dapat dikatakan bahwa koperasi tidak cukup memiliki kemampuan yang lebih dalam menyelesaikan kewajiban lancarnya hanya dengan menggunakan arus kas operasinya di tahun tersebut tanpa dukungan aktivitas lain dari pemanfaatan arus kas koperasi.

Rasio Arus Kas Terhadap Laba Bersih
Rasio arus kas operasi terhadap laba bersih menunjukkan seberapa jauh penyesuaian dan asumsi akuntansi aktual mempengaruhi perhitungan laba bersih. Semakin tinggi rasio ini menunjukkan kinerja keuangan perusahaan semakin baik, meskipun dengan jumlah laba bersih yang kecil sebagai akibat besarnya beban non kas.

Tabel 5

Hasil Perhitungan Rasio Arus Kas Terhadap Laba Bersih

\begin{tabular}{|c|c|c|}
\hline Tahun & Hasil Perhitungan & Presentase \\
\hline 2016 & $-0,839$ & $-83,9 \%$ \\
\hline 2017 & $-0,037$ & $-3,7 \%$ \\
\hline
\end{tabular}

Sumber : Data diolah menggunakan Excel, 2019

Berdasarkan perhitungan pada tabel 5 hasil perhitungan terlihat bahwa dari tahun 2016 dan tahun 2017 laba meningkat karena pendapatan perusahaan lebih besar.

Pada tahun 2016, rasio arus kas operasi terhadap laba bersih yang dihasilkan adalah sebesar -0,839 dapat dikatakan kinerja perusahaan kurang baik, karena hasil perhitungan yang dihasilkan kurang dari satu dan mengalami angka yang negatif serta belum memenuhi standar. . Pada tahun 2017 rasio arus kas operasi terhadap laba bersih yang dihasilkan adalah sebesar 0,037, karena rasio yang dihasilkan kurang dari standar satu dan juga mengalami angka yang negatif maka dapat dikatakan kinerja perusahaan kurang baik, yang berarti ketidakmampuan perusahaan dalam mendanai kegiatan operasi dengan menggunakan kas masuk dari aktivitas operasi itu sendiri.
Jadi kesimpulannya, rasio arus kas terhadap laba bersih setiap tahunnya dapat dikategorikan kurang baik karena kurang dari standar 1 dan mengalami angka yang negatif.

\section{PENUTUP \\ KESIMPULAN}

Berdasarkan uraian yang telah dipaparkan pada bab - bab sebelumnya maka dapat disimpulkan bahwa :

a. Rasio arus kas operasi terhadap kewajiban lancar koperasi setiap tahunnya menunjukkan nilai yang rendah dan dapat dikategorikan kurang baik karena kurang dari standar rasio yaitu satu.

b. Cakupan arus kas terhadap bunga pada Koperasi Kredit Sedana Padang Asri, untuk tahun 2016 adalah kurang dari 31 kali lipat total arus kas operasi yang dimiliki oleh koperasi. Sedangkan pada tahun 2017 mengalami peningkatan dalam menutup biaya bunga yaitu hampir 2 
kali dari total arus kas operasi yang dimiliki oleh koperasi.

c. Rasio total hutang koperasi setiap tahunnya menunjukkan nilai yang rendah dan dapat dikategorikan kurang baik karena kurang dari standar rasio yaitu satu, maka dapat dikatakan bahwa koperasi tidak cukup memiliki kemampuan dalam menyelesaikan total hutangnya tanpa dukungan aktivitas lain dari pemanfaatan arus kas koperasi.

d. Rasio arus kas terhadap laba bersih setiap tahunnya dapat dikategorikan kurang baik karena kurang dari standar 1 dan mengalami angka yang negatif.

Dari penjelasan diatas tingkat likuiditas Koperasi Kredit Sedana Padang Asri memperlihatkan kondisi yang kurang baik jika diperbandingkan dengan nilai rasio yang dipersyaratkan berada di bawah satu.

\section{SARAN-SARAN}

Dari kesimpulan yang telah diuraikan diatas, maka selanjutnya dapat diberikan saran yaitu sebagai berikut :

a. Kredit Sedana Padang Asri harusnya menjaga likuiditasnya berdasarkan pada laporan arus kasnya terutama pemanfaatan arus kas operasi, investasi dan pendanaan. Pemanfaatan aktivitas yang dimaksudkan adalah agar perusahaan menempatkan penggunaan arus kasnya pada investasi jangka pendek seperti pembayaran kewajiban yang kecenderungan pengembaliannya lebih cepat agar pembayaran kewajiban jangka pendeknya dapat terpenuhi tepat waktu.

b. Bagi Peneliti Selanjutnya

Penelitian selanjutnya sebaiknya menambah rentang waktu penelitian dan penilaian dengan rasio keuangan, misalnya : rasio solvabilitas, rasio aktivitas, rasio rentabilitas, dan rasio profitabilitas yang tidak hanya berdasarkan arus kas, sehingga mampu menghasilkan penilaian kinerja keuangan secara lebih detail.

c. Rasio arus kas operasi terhadap kewajiban lancar koperasi setiap tahunnya menunjukkan nilai yang rendah dan dapat dikategorikan kurang baik karena kurang dari standar rasio yaitu satu.

d. Cakupan arus kas terhadap bunga pada Koperasi Kredit Sedana Padang Asri, untuk tahun 2016 adalah kurang dari 31 kali lipat total arus kas operasi yang dimiliki oleh koperasi. Sedangkan pada tahun 2017 mengalami peningkatan dalam menutup biaya bunga yaitu hampir 2 kali dari total arus kas operasi yang dimiliki oleh koperasi.

e. Rasio total hutang koperasi setiap tahunnya menunjukkan nilai yang rendah dan dapat dikategorikan kurang baik karena kurang dari standar rasio yaitu satu, maka dapat dikatakan bahwa koperasi tidak cukup memiliki kemampuan dalam menyelesaikan total hutangnya tanpa dukungan aktivitas lain dari pemanfaatan arus kas koperasi.

f. Rasio arus kas terhadap laba bersih setiap tahunnya dapat dikategorikan kurang baik karena kurang dari standar 1 dan mengalami angka yang negatif. 


\section{DAFTAR PUSTAKA}

$\begin{array}{ccr}\text { Baswir,Revisond. } & \text { (2013). } & \text { Koperasi } \\ \text { Indonesia. } & \text { Edisi } & \text { Kedua. } \\ \text { Yogyakarta: } & \text { BPFE. } & \end{array}$

Carl S. Warren, et al. (2014). Accounting Indonesia Adaptation. Jakarta : Salemba Empat.

Fahmi, Irham. (2014). Pengantar Manajemen Keuangan. Bandung: Alfabeta

Hanafi, Mamduh M. dan Abdul Halim.(2014). Analisis Laporan Keuangan. Edisi tujuh, Yogyakarta : UPP AMP YKPN.

Hani, Syafrida. (2015). Teknik Analisa Laporan Keuangan. Medan :In Media.

Hery. (2015). Analisis Laporan Keuangan. Edisi 1. Yogyakarta: Center For. Academic Publishing Services.

Ikatan Akuntansi Indonesia. (2013). PSAK No. 2(Revisi 2013). Jakarta : IAI

Ikatan Akuntansi Indonesia. PSAK No. 2 Tentang Laporan Arus Kas- edisi revisi (2014). Penerbit Dewan Standar Akuntansi Keuangan: PT. Raja Grafindo

Ikatan Akuntan Indonesia. (2015). Pernyataan Standar Akuntansi Keuangan. Jakarta : Ikatan Akuntan Indonesia

Kartasapoetra, G., et al. (2013). Koperasi Indonesia. Jakarta: PT Rineka Cipta.

Kasmir. (2014). Analisis Laporan Keuangan. Edisi Satu. Cetakan Ketujuh. Jakarta : PT Raja Grafindo Persada.
Muljono, Djoko. (2013). Buku Pintar Strategi Bisnis Koperasi Simpan Pinjam.Yogyakarta: Andi

Rudianto. (2015). Akuntansi Koperasi. Edisi Kedua. Jakarta: Erlangga.

Sudana, I Made. (2015). Manajemen Keuangan Perusahaan. Edisi Kedua. Jakarta : Erlangga

Sudarwanto, Adenk. (2013). Akuntansi Koperasi. Yogyakarta: Graha Ilmu Sugiyono. (2014). Metode Penelitian Pendidikan Pendekatan Kuantitatif, Kualitatif dan Kombinasi (Mixed. Methods). Bandung: Alfabeta

Sugiyono. (2016). Metode Penelitian Kuantitatif, Kualitatif dan $R \& D$. Bandung: PT Alfabet.

Undang-Undang tentang Perkoperasian Nomor 17 Tahun 2012

Afiq, Syahrul. (2017). Analisis Laporan Arus Kas Untuk Mengukur Likuiditas Pada Ksu. Sri Lestari ( Studi Kasus Pada Ksu. Sri Lestari Udanawu ). Simki-Economic Vol. 02 No. 03 Tahun 2018 ISSN : 2599-0748

Debby Mogi, Chintia dkk. (2016). Analisa Laporan Arus Kas Sebagai Dasar Pengukuran Likuiditas Pada Perusahaan "Unicare" Cabang Manado. Jurnal Berkala Ilmiah Efisiensi Volume 16 No. 01 Tahun 2016

Diah Rahayu, Nurvita. (2015). Analisis Arus Kas Dalam Menentukan Tingkat Likuiditas Perusahaan (Studi Kasus pada Koperasi Jasa Keuangan Syariah (KJKS) Mawar Karanggeneng, Kabupaten Lamongan Periode Januari Oktober 2013). Jurnal Akuntansi Integratif Vol. 1, No.1, April 2015 
Mustakim dkk. (2016). Analisis Arus Kas

Dalam Menentukan Tingkat

Likuiditas Perusahaan Pada PT.

Pelabuhan Indonesia (PELINDO)

III Cabang Celukan Bawang. $E$
Journal Universitas Pendidikan Ganesha Jurusan Akuntansi

Program S1(Vol: 6 No: 3 Tahun 2016 